\title{
The Use of CDME in Cystinosis Research
}

\author{
Martijn J. Wilmer - Lambertus P. van den Heuvel • \\ Elena N. Levtchenko
}

Accepted: 3 April 2008/Published online: 22 April 2008

(C) The Author(s) 2008

Sirs,

With interest we have read the article entitled "Antioxidant effect of cysteamine in brain cortex of young rats" by Kessler et al. [1]. In their study, they showed that cysteamine reduces the oxidative stress caused by administration of cystine dimethyl ester (CDME) in Wistar rats.

In contrast to the antioxidant effects of cysteamine via increased production of glutathion, Jeitner and Lawrence showed that a higher dose of cysteamine induced cytotoxicity by enhanced $\mathrm{H}_{2} \mathrm{O}_{2}$ production [2]. In addition, the proposed antioxidant effects of cysteamine observed in rats with CDME administration can be different in patients with cystinosis, as Kessler et al. mentioned in their recent paper.

Because research to the pathogenesis of cystinosis was hampered by the lack of a proper in vitro model, many studies have used CDME for its ability to artificially load lysosomes with cystine, mimicking lysosomal cystine accumulation in cystinosis. This technique has been developed in the 70s by Goldman and Reeves [3, 4]. Using CDME loading, alterations in ATP metabolism and increased apoptosis have been demonstrated [5, 6]. More recent studies in human cystinotic tissues indicated the involvement of oxidative stress, possibly via alterations in glutathion metabolism [7-9].

Our group has recently shown that loading of cultured fibroblasts and human proximal tubular cells with CDME

M. J. Wilmer $(\bowtie)$. L. P. van den Heuvel

Laboratory of Pediatrics and Neurology (656), Radboud

University Nijmegen Medical Centre, P.O. 9101, 6500 HB

Nijmegen, The Netherlands

e-mail: m.wilmer@cukz.umcn.nl

E. N. Levtchenko

Department of Pediatrics, University Hospital Leuven,

Leuven, Belgium has a direct impact on the viability of the cells by irreversible inhibition of the mitochondrial ATP production and burst of superoxide in the cells [10]. These major effects were not observed in cystinotic cells with comparable cystine levels due to mutations in the CTNS gene. This indicates a direct toxic effect of CDME, independent of cystine accumulation.

Based on these data we recommend that the use of CDME should be limited for studying the pathogenesis of cystinosis and conclusions drawn using this model need re-evaluation. Instead, more appropriate cell and animal models with defective CTNS, which already have been developed by several groups, can be used for this purpose [11-13].

Open Access This article is distributed under the terms of the Creative Commons Attribution Noncommercial License which permits any noncommercial use, distribution, and reproduction in any medium, provided the original author(s) and source are credited.

\section{References}

1. Kessler A, Biasibetti M, da Silva Melo DA et al (2008) Antioxidant effect of cysteamine in brain cortex of young rats. Neurochem Res 33(5):737-744

2. Jeitner TM, Lawrence DA (2001) Mechanisms for the cytotoxicity of cysteamine. Toxicol Sci 63(1):57-64

3. Goldman R, Kaplan A (1973) Rupture of rat-liver lysosomes mediated by L-amino-acid esters. Biochem Biophys Acta 318(2):205-216

4. Reeves JP (1979) Accumulation of amino-acids by lysosomes incubated with amino-acid methyl-esters. J Biol Chem 254(18):8914-8921

5. Coor C, Salmon RF, Quigley R et al (1991) Role of adenosinetriphosphate (ATP) and NaK ATPase in the inhibition of proximal tubule transport with intracellular cystine loading. J Clin Invest 87(3):955-961

6. Park M, Helip-Wooley A, Thoene J (2002) Lysosomal cystine storage augments apoptosis in cultured human fibroblasts and renal tubular epithelial cells. J Am Soc Nephrol 13(12):2878-2887 
7. Corcoran GB, Fix L, Jones DP et al (1994) Apoptosis: molecular control point in toxicity. Toxicol Appl Pharmacol 128(2):169-181

8. Laube GF, Shah V, Stewart VC et al (2006) Glutathione depletion and increased apoptosis rate in human cystinotic proximal tubular cells. Pediatr Nephrol 21(4):503-509

9. Mannucci L, Pastore A, Rizzo C et al (2006) Impaired activity of the gamma-glutamyl cycle in nephropathic cystinosis fibroblasts. Pediatr Res 59(2):332-335

10. Wilmer MJ, Willems PH, Verkaart S et al (2007) Cystine dimethylester model of cystinosis: still reliable? Pediatr Res 62(2):151-155
11. Laube GF, Haq MR, van't Hoff WG (2005) Exfoliated human proximal tubular cells: a model of cystinosis and Fanconi syndrome. Pediatr Nephrol 20(2):136-140

12. Wilmer MJG, Graaf-Hess A, Blom HJ et al (2005) Elevated oxidized glutathione in cystinotic proximal tubular epithelial cells. Biochem Biophys Res Commun 337(2):610-614

13. Cherqui S, Sevin C, Hamard G et al (2002) Intralysosomal cystine accumulation in mice lacking cystinosin, the protein defective in cystinosis. Mol Cell Biol 22(21):7622-7632 